\title{
15
}

\section{Russia: Public Debate and the Petroleum Sector}

\section{Nina Poussenkova and Indra Overland}

\section{Introduction}

Russia is the world's largest oil and gas exporter and has a petroleum history going back to the country's first oil well and refinery in the town of Ukhta in the Komi Republic in 1745 . For a country that is ranked relatively low on most indices of democracy, the involvement of Russian civil society in the petroleum sector has been surprisingly diverse and active in the post-Soviet period. However, civil society's actual influence is limited and declining.

N. Poussenkova $(\bowtie)$

Institute for World Economy and International Relations,

Russian Academy of Sciences, Moscow, Russia

I. Overland

Head of the Energy Programme, Norwegian Institute of International Affairs (NUPI), Oslo, Norway 
In this chapter, we provide an empirical overview of the evolution of civil society engagement in the country's petroleum sector from the dissolution of the Soviet Union in 1991 up to 2017. We start by looking at it periodically_-first the 1990s and then the 2000s — and subsequently examine the roles of specific types of actors: political parties, industry associations, non-governmental organizations (NGOs), indigenous groups, various media and the general public.

\section{The 1990s}

The 1990s were a period of dramatic social, economic and political upheaval in Russia, with the dissolution of the Soviet Union, a weakening state and the rise of gangster capitalism and strong oligarchs. Oil prices were low, Russian oil production was declining rapidly, privatization of the oil industry was underway and the state company Rosneft was in decline. During these years, big business and oligarchs determined the rules of the game in the petroleum sector. Practically all key energy-policy decisions were heavily lobbied by corporate actors keen to carve out wealth for themselves from Soviet oil and gas assets.

Thus, post-Soviet market reforms in the oil sector-including the infamous loans-for-shares scheme whereby major Russian companies were handed over to insiders via rigged auctions - were generally initiated by oilmen. Gazprom was founded on the basis of the Soviet Ministry of the Gas Industry in 1989. The next major transformation of the petroleum sector came with Presidential Decree 1403, which created the private oil companies LUKOIL, Yukos and Surgutneftegas, as well as the state companies Rosneft, Transneft and Transnefteprodukt (Russian President 1992). The new companies were established largely in line with the interests of the powerful individuals who became their presidents. For example, Vagit Alekperov, a former First Deputy Oil Minister, due to his political connections, could hand-pick attractive assets for LUKOIL. In 1994-1995, Slavneft, SIDANCO, Sibneft and TNK were established on the basis of assets from the state-owned oil company Rosneft; consequently, Rosneft shrank rapidly. The unexpected creation of the oil 
company Sibneft by a special Presidential Decree on 24 August 1995 posed a further challenge to Rosneft (Poussenkova 2007).

In the 1990s, the oilmen had a powerful lobby in the State Duma: this was the New Regional Policy Party headed by the chairman of the Union of Oil Industrialists, Vladimir Medvedev. In 1994, the Interregional Association of Economic Interaction was formed in the Federation Council, led by Senator Yuri Shafranik, then Minister of Fuel and Energy. Big business also made active use of the mass media under its control to pursue its own goals: LUKOIL owned $41 \%$ of the newspaper Izvestia, UNEXIM owned 20\% of the newspaper Komsomolskaya pravda and cooperated closely with the magazine Expert, SBS-Agro was connected with the Kommersant publishing house and MENATEP had close relations with the Moscow Times (Poussenkova 2011).

The 1990s were also a period when real political opposition existed, as the 1995 State Duma elections and the 1996 presidential elections demonstrated. In December 1995, the Communist Party became the largest party in the Duma with $22 \%$ of the vote, whereas President Yeltin's party, Our Home, received only $10 \%$. Yeltsin's popularity had also evaporated, mainly because of the failure of economic reforms, the war in Chechnya and corruption. His presidential election campaign was conducted under the slogan 'vote or lose', with full control over television and with the support of oligarchs such as Boris Berezovsky, Vladimir Gusinsky, Vladimir Potanin, Mikhail Fridman and Mikhail Khodorkovsky. It is noteworthy that Gazprom was used to help Yeltsin win the elections: in 1996 , the gas monopoly borrowed 40 trillion roubles, which the government spent on paying pensions arrears (Popov 2007).

During the 1990s, the opposition parties had some impact on the development of the petroleum sector in Russia. For example, the Yabloko party was fairly active on oil and gas issues, especially in promoting production-sharing agreements as a way of attracting foreign investment to the sector. In 2003, when it became clear that oil prices were growing steadily, Yabloko leader Grigory Yavlinsky proposed the creation of the Stabilization Fund (Yabloko 2016). Later, however, Yabloko became gradually marginalized in politics, due to repressive measures and declining popularity. 
Though Soviet science collapsed during the 1990s, this period also saw many academics achieve high-level positions in government. A key driver and ideologue of economic reform in Russia was Egor Gaidar, an academic with a $\mathrm{PhD}$ in economics, who initiated privatization and managed the process of transition to a market economy. Academician Evgeniy Primakov was Chairman of the Government in 1998-1999. Academics were particularly well-represented in the Ministry of Fuel and Energy: Vladimir Lopukhin served as Minister 1991-1993, Andrei Konoplyanik as Deputy Minister 1991-1993 and Elena Telegina as Deputy Minister 1997-1999.

The 1990s were a period when glasnost began to influence the petroleum sector, especially in connection with environmental essues. When there was a large oil spill from an old pipeline in the Komi Republic in 1994, top managers of the company responsible, Komineft, managed to hush up the catastrophe for more than a month, in keeping with the Soviet tradition of secrecy. However, when information inevitably reached the public, Russian and international media provided extensive coverage of the accident, and environmental NGOs such as Greenpeace actively supported the protests of the local population (Energy Future 2010; Neftyanka 2015).

During the 1990s, there was a trend towards decentralization in Russia. Regional authorities exerted considerable influence on the development of the oil and gas sector in their regions, largely through the 'two-keys' principle: the use of subsurface resources was the joint responsibility of the federal centre and the regions, and the centre and the regions had equal rights (Article 72 of the Russian Constitution). In February 1994, a treaty was signed between the Republic of Tatarstan and Russia on the delimitation of competences and delegation of authority, and special agreements were concluded on the oil sector. During the 1990s, the government of Tatarstan pursued an energy policy that was relatively independent of Moscow and that provided significant fiscal benefits to Tatneft. As a result, the company, with its mature fields, managed to halt the oil production decline, maintaining output at some 24 million tons per year.

To sum up, the 'roaring 1990s' in Russia was a period of social and economic dissolution, decentralization and diversification. The emergent 
civil society had some impact on the development of the country's petroleum sector-but far more influential were various powerful business people and politicians operating within the petroleum sector.

\section{The 2000s}

From the year 2000 onwards, oil prices rose, crude production began to rise again and life in Russia started stabilizing. This was a period of increasingly authoritarian capitalism and a strengthening state, with further consolidation of the petroleum sector, its creeping renationalization and a renaissance for Rosneft, which started to compete with Gazprom on many fronts (Lunden et al. 2013). Simultaneously, the state tightened its grip on the mass media, freedom of the press was suppressed, liberals were squeezed out of central positions, the opposition was persecuted, strict limitations were placed on NGOs and international oil companies had to cope with rising resource nationalism (on the media, see Jackson 2016, 354).

Vladimir Putin's first presidential term, 2000-2004, was a transition period when a new energy policy was not yet fully formulated. Steps were taken to further liberalize the energy sector: privatization of the oil and coal industry continued, and a programme of market reforms in power generation was approved. However, the government simultaneously increased its influence in the petroleum sector. It banned private pipelines, strengthened state control over Gazprom and postponed reform of the gas export monopoly (Milov and Selivakhin 2005; Overland 2017).

During Putin's second term in office, the attitude of the authorities towards the petroleum sector changed abruptly. After the cabinet of Mikhail Kasyanov resigned in 2004, its successor, the government of Mikhail Fradkov, ceded the initiative on key policy decisions in the energy sector to the President and his administration. The state started intervening far more actively in the oil and gas industry. The fourth State Duma, elected in December 2003, also contrasted starkly with the third State Duma. The new, strong pro-presidential majority made possible the swift passing of legislation. There were still numerous oilmen in the Duma, but they started complying with presidential policy. 
The political influence of the oligarchs and heads of petroleum-rich federation subjects subsided. Seeking to deprive the oil and regional barons of their sources of economic power, in August 2004 the State Duma adopted amendments to the Law on Subsurface Resources that abolished the 'two-keys' principle. Moscow took control of licensing: decisions on issuing licenses were now to be made by a federal commission, and the regions were left with only an advisory role in the tenders (Chernobylets and Shadrina 2006).

The power of the once-mighty private oil companies also waned. In the early 2000s, Yukos had been the largest Russian oil company and a trailblazer in many areas. For example, Mikhail Khodorkovsky initiated important pipeline projects that could have significantly expanded Russia's export potential, in addition to giving Yukos better access to foreign markets. Of particular importance was the Murmansk oil pipeline planned by Yukos, Sibneft, LUKOIL, TNK and Surgutneftegas in 2003 (Moe et al. 2011; Overland and Krivorotov 2015).

This unprecedented promotion of private pipelines in Russia and the role of Yukos had posed a serious challenge to the state oil pipeline company, Transneft. It may also have angered the political authorities, since export pipelines in Russia had always been seen as not only transportation infrastructure but also powerful instruments of government energy policy (Orttung and Overland 2011). Mikhail Kasyanov, then Prime Minister, declared that there would be no private pipelines in Russia (Ignatova 2003). And in 2003 the Yukos case started: first Platon Lebedev and then Mikhail Khodorkovsky were arrested, and the destruction of the previously mighty company commenced, aided and abetted by Rosneft (Leonard 2016). The Yukos case marked the end of the Russia of the 1990s and the entrenchment of the new Russia of Vladimir Putin.

Whereas the influence of private oil companies was in decline, the lobbying power of the state companies was on the rise. Gazprom and Rosneft became national champions: it was expected that these companies, by virtue of their vast hydrocarbon reserves and administrative resources, would be able to compete with the global oil majors, protect the national hydrocarbons resources and implement the desired energy policy. These state companies in turn lobbied for changes in the fiscal legislation, in order to ensure an attractive tax regime for their projects and ultimately 
the exclusion of all other companies from Russia's continental shelf and the Arctic (Overland 2010; Overland et al. 2013).

In the current Russian context, big business remains the most powerful player by far. However, in addition, there are several types of non-governmental actors that might influence oil and gas policy: professional organizations and associations, small and medium-sized oil and gas companies, the political opposition, researchers and think-tanks, NGOs, including environmental and indigenous rights groups, the media, institutions of higher education and the general population. Their roles are discussed in the following sections.

\section{Business Associations}

The Russian Union of Industrialists and Entrepreneurs (RSPP) promotes the interests of the Russian business community, bringing together more than 100 sectoral and regional associations. RSPP consists of several committees, including the Committee on Energy and Energy Efficiency. This committee is headed by Vagit Alekperov, president of Russia's largest private oil company, LUKOIL, and is therefore influential. It is clear from the list of individuals whose views on energy issues were posted on the committee's website in 2016 that it is very much a pro-establishment organization (RSPP 2016).

The Chamber of Trade and Industry (TPP) is a non-governmental, non-commercial organization that represents the interests of small, medium-sized and big businesses, embracing all spheres of entrepreneurship (TPP 2016). For a long time, the TPP's high status and influence was linked to its president, Evgeniy Primakov, a popular Russian politician who headed the organization from 2001 to 2011. His successor, Sergei Katyrin, is a lower-profile figure, and under him TPP has lost some of its clout. Recent legislative proposals put forth by TPP concerning the petroleum sector include draft amendments to the Law on Subsurface Resources, the draft law On Organizing an Experiment of Gas Sales at Market Prices on Commodity Exchanges, an initiative for a resource base of the oil and gas complex of Russia and problems of subsurface use and a concept for state management of rational use of oil reserves. 
In addition to these general trade organizations, there are several others specific to the petroleum sector: the Russian Gas Society (RGO), a 'pocket' organization of Gazprom, the Union of Oil and Gas Industrialists of Russia and the Association of Independent Oil and Gas Producers (AssoNeft), which seeks to protect the interests of small and mid-size nonintegrated oil companies (without much success). The most influential of these organizations is the Russian Gas Society, which actively promotes the interests of Gazprom, through its President, Pavel Zavalniy, who also chairs the Committee on Energy of the State Duma. In addition, RGO develops relevant legislation, rules and standards, provides advisory services and acts as an arbitration court.

\section{The Political Opposition}

After the year 2000, because of the increasingly strict limitations in election legislation and the tightening of state control over the main media, television in particular, a new form of opposition dubbed the "nonsystemic' opposition emerged but was effectively denied access to elections. It came to include left-wing forces, right-wing forces and nationalists. In addition, there is what is known as the 'systemic opposition', consisting mainly of the Communist Party, the Liberal Democratic Party (LDPR) and A Just Russia. It is represented in the State Duma and the regional authorities and in practice cooperates with the government.

The nonsystemic opposition suffers from serious government repression, in the form of denial of registration by the Ministry of Justice and other legal-bureaucratic obstacles and censorship in key mass media, especially the national television channels (Gilbert 2016, 1553). It has only limited influence on how petroleum resources are managed, and its actions aimed at the powerful state oil and gas companies seem doomed to failure.

An important opposition figure is Alexei Navalny, who has profiled himself as an anti-corruption crusader. A considerable part of his activity has targeted the petroleum sector. In 2008, Navalny bought a symbolic 
number of shares in Gazprom, Gazprom Neft, LUKOIL, Rosneft and Surgutneftegas, thus becoming a minority shareholder. The idea was to exert pressure on the companies over issues of non-transparency and corruption. In 2010, he published secret documents about the auditing of Transneft, indicating that approximately 4 billion dollars had been embezzled by Transneft's leaders during the construction of the Eastern Siberia-Pacific Ocean oil pipeline (ESPO). Navalny also tried to identify where Transneft was channelling its outsized charitable allocations; however, the Office of Economic Crimes refused to start criminal proceedings because Transneft did not respond to the queries of the police (Malkova 2010). Alexei Navalny has been subjected to significant pressure from the authorities, including being indicted and convicted of corruption, put under house arrest, and his brother Oleg Navalny being sentenced to several years in prison.

Opposition experts and politicians often present their views to the public by writing analytical reviews about the situation in the country, including its energy sector. Vladimir Milov and Boris Nemtsov published a book in which they tried to determine what 10 years of Putin's rule had meant for Russia (Milov and Nemtsov 2010). The chapter 'Russia: Raw Materials Appendage' analysed the problems created by Russia's oil and gas dependency. There the authors argued that the dependency of Russia on its hydrocarbon reserves increased during Putin's rule; that despite the unprecedentedly high oil prices, the Russian economy grew more slowly than it could have; moreover, that no real efforts were made to modernize the country; assets were expropriated and more and more was spent on the growing state apparatus, the special services and on financing state corporations.

Equally interesting is Putin and Gazprom, also authored by Milov and Nemtsov (2008). Here they describe Gazprom as Putin's main personal project, emphasizing that the reliability of the Russian gas supply is deteriorating. They focus on shady deals involving stripping of assets from Gazprom, including purchases of assets and pipeline construction. This extract from Putin and Gazprom says much about the weakness of civil society in Russia in the absence of real freedom of the press: 
While in the late 1990s actions related to the stripping of assets [from Gazprom] became known by the public ... and were commented on extensively by independent mass media, during the second term of Putin's presidency, given the increasing suppression of freedom of press, the public was not well aware of the second wave of asset stripping. The business press that is not controlled by Putin wrote about it, but its circulation is too small, and the audience is too narrow for this information to receive a broad dissemination. Russian TV is silent about such deals - for obvious reasons. (Milov and Nemtsov 2008)

However, the liberal and democratic opposition in Russia appeals to only a small segment of the population. The works by Milov and Nemtsov are popular mainly among the intelligentsia and people with higher education. Vladimir Milov has written critical columns for the newspaper Vedomosti, also reaching a limited number of readers. On Facebook, his postings continue to attract much attention and commentary, but again the audience is small. Perhaps Milov's greatest weakness is that he is good at formulating criticism, but does not always have constructive alternatives to propose.

Boris Nemtsov was shot and killed in 2015 while walking near the Kremlin (Sergeev et al. 2015). Nemtsov's fate is illustrative of the trajectory of independent voices in Russian petroleum-policy formulation: he went from Deputy Prime Minister with special responsibility for energy issues under President Yeltsin in the 1990s to being a member of the opposition who spoke out loud and clear on energy issues and was then assassinated in 2015.

The political opposition also includes other liberals who were displaced from the establishment, such as Andrei Illarionov, who was economic advisor to the President from 2000 to 2005. In this position, he often criticized the activities of the authorities but without much effect. For example, he advised the authorities to leave the Yukos oil company alone-only to see it dismantled. On 27 December 2005, Illarionov resigned, stating that a change of political regime had taken place in Russia during Putin's rule, and he, even being advisor to the President, could no longer freely express his opinion (Lenta.ru 2016). He continued to express his critical opinion as part of the opposition. 
Another example is the former Minister of Finance Alexei Kudrin, who left the government after a spat with Prime Minister Dmitry Medvedev and has consistently argued for the government to rein in its spending of oil and gas revenues (and not to use the National Wealth Fund for financing oil and gas projects). As an old associate of President Vladimir Putin who has chosen to stand outside the government, Kudrin represents a position between the opposition and the government.

\section{Environmental NGOs}

Several environmental NGOs operate in Russia, also in the petroleum sector. They are sometimes regarded with suspicion by the establishment, because they are thought to be acting in the interest of foreign countries, seeking to undermine the competitiveness of Russian business by insisting on strict environmental standards (for further discussion, see Lee et al. 2012). Their existence became increasingly precarious after the adoption in 2006 of a new law on NGOs and again with amendments in 2012 to the Law on Non-Commercial Organizations (Crotty et al. 2014). Under these amendments, Russian non-commercial organizations that receive funding from abroad and are involved in political activities are classified as 'foreign agents' (Gosudarstvennaya Duma 2012).

WWF Russia is an influential environmental NGO in Russia. Part of its success may lie in its approach, which involves seeking constructive cooperation with companies, rather than confrontation. WWF Russia is particularly active in the petroleum sector, where it aims to reduce the negative impacts of the oil and gas industry. Owing to the efforts of WWF Russia, Sakhalin Environment, Western Grey Whale Advisory Panel and other organizations, seismic activities in the framework of Sakhalin-1 project that could have destroyed the grey whales of the Western-Pacific group were halted.

In 2007, when over 4000 tons of fuel oil were spilled in connection with an accident in the Kerch Strait between the Black Sea and the Sea of Azov, WWF Russia began to focus on oil spills. For the first time in Russia, WWF organized activities to rescue oil-covered birds. WWF Russia jointly with other environmental organizations interacts with the 
legislative and executive authorities in order to improve legislation concerning oil spills. On 28 November 2007, WWF Russia together with Greenpeace, the Union for Protection of Birds of Russia, Environmental Watch of Sakhalin, Friends of Siberian Forests, Centre of Environmental Education of the Sakha Republic and other organizations submitted an appeal 'No to New Oil Spills in Russia' to the State Duma, the Federation Council and the government, insisting on urgent measures to solve the problem, including development of the law 'On the Protection of the Seas from Oil Pollution'. The concept of the law was formulated in 2009 on the initiative of WWF Russia. A draft law was developed on the basis of this concept, approved by the Duma and signed by the President; it entered into effect on 1 July 2013 (WWF 2016).

\section{The East Siberia-Pacific Ocean Pipeline}

Another example of a petroleum project where environmental NGOs and civil society groups were able to exert influence is the rerouting of the East Siberia-Pacific Ocean Pipeline (ESPO), so that it would bypass Lake Baikal. On 31 December 2004, Prime Minister Mikhail Fradkov signed a decree on the construction of ESPO from Taishet to Skovorodino to Perevoznaya Bay. Initially, the state oil pipeline company Transneft planned to lay the pipeline some 800 metres from the northern shores of Lake Baikal in a seismically active zone with earthquakes reaching 10 degrees on the Richter Scale. Environmental NGOs, including WWF Russia, Baikal Environmental Wave, Greenpeace and Friends of the Earth, protested loudly, pointing out that the proposed pipeline would pass through permafrost areas, regions with complicated geographic, geological and hydrological features and cross the main rivers of the Baikal basin. Thousands of people signed a letter to Vladimir Putin drafted by WWF Russia, requesting his help in protecting Lake Baikal from ESPO.

Scientists joined forces with the environmental NGOs. They protested against Transneft's plan to make Perevoznaya Bay the endpoint of the pipeline, where it would threaten two nature reserves, the habitat of the Far-Eastern leopard, as well as the fisheries of Primorsk Krai. The State 
Environmental Expert Review twice rejected the proposed pipeline route, which, as noted, would pass some 800 metres north of Baikal. Transneft retorted that moving the route further north would be too expensive, as it would then pass through uninhabited mountain areas. However, in April 2006, Vladimir Putin met with scientists in the Siberian city of Tomsk, listened to the proposals of Nikolai Laverov, vice president of the Russian Academy of Sciences, and then ordered Transneft to move ESPO from the shores of Baikal at least $40 \mathrm{~km}$ further north. Ultimately, the pipeline was built $400 \mathrm{~km}$ to the north of Baikal.

In this case, the normally politically passive Russians were protesting not against a top-down decision that affected their personal well-being but against potential environmental damage, and their protest seemed to make a difference. Still, a nagging question remains unanswered: what was it that really led Putin to decide to have the pipeline rerouted - the environmental protests or the fact that the rerouted ESPO passed close to the Irkutsk and Yakutsk oilfields of Rosneft, Surgutneftegas and TNK-BP, which thus benefited from the decision to move the pipeline? Or did Putin want to be remembered as the man who saved Baikal from the irresponsible actions of the state oil pipeline company?

Another high-profile case where Russian and international environmental NGOs did appear to have influence during this period involved the Sakhalin-2 project. Here it seems that the authorities allowed the NGOs and indigenous peoples to win: their environmental criticism aimed at Sakhalin Energy (then owned by Shell, Mitsubishi and Mitsui) was used as a convenient pretext by the Russian government to enable Gazprom to join the project as majority shareholder on favourable terms (Overland 2011).

\section{Indigenous Peoples}

According to Russian legislation, indigenous peoples have a right to participate in public hearings concerning new petroleum projects. But the problems faced by the Russian Association of Indigenous People of the North, Siberia and the Far East (RAIPON) from around 2010 onwards show that their influence is in practice limited. 
RAIPON sought to influence the petroleum industry in favour of the indigenous peoples and openly discussed hot issues in the press and at domestic and international events (Berezhkov 2012). In August 2012, delegates from Komi, Nenets and Yamal-Nenets autonomous regions, the Russian Sámi parliament and RAIPON attending the conference 'Arctic Oil: Implications for Indigenous Peoples' in Usinsk demanded that oil production on the Arctic shelf be banned; a moratorium on Arctic onshore oil drilling be introduced, and rights of indigenous peoples for their land be recognized by law. One appeal was addressed to the government of Russia, the second, to the global community (Greenpeace Russia 2012). Was it a coincidence that on 1 November 2012, the Ministry of Justice ordered RAIPON to halt its activity, claiming that its charter did not comply with current legislation? For further discussion of corporate social responsibility and citizens as stakeholders in Arctic oil extraction in Russia, see Henry et al. (2016).

In March 2013, after prolonged legislative and public relations battles, RAIPON's charter was amended, and its problems ended for the time being, thanks mainly to the support of the regional authorities and deputies in the State Duma, primarily Grigoriy Ledkov, from the YamalNenetsk Autonomous Region. He stressed the importance of establishing constructive dialogue with the indigenous peoples, particularly in view of the planned development of the Arctic.

\section{Think-Tanks, Experts and Educational Institutions}

Academic and analytical experts draft energy strategies for Russia, provide advice to the government, professional organizations and businesses, carry out projects jointly with NGOs, are invited to write articles or make comments for printed mass media or appear on TV or radio programmes and they teach at institutions of higher education. They have some influence, but the policymakers listen mainly to what they want to hear. These experts can be divided into the following groups: pro-Kremlin political scientists (e.g. Konstantin Simonov, of the National Energy Security Fund), government-affiliated economists (e.g. Leonid Grigoriev of the 
government's Analytical Center), those affiliated with Gazprom or Rosneft (e.g. Andrei Konoplyanik, Vladimir Feigin), moderates (e.g. Tatiana Mitrova of the Institute of Energy Studies), technical (e.g. Igor Bashmakov of the Center for Efficient Use of Energy), critical (e.g. Mikhail Krutikhin of RusEnergy), oppositional (e.g. Vladimir Milov of the Institute of Energy Policy) and neutral oil and gas analysts working for Russian and foreign investment banks or auditing companies (e.g. Valery Nesterov of Sberbank).

The Russian Academy of Sciences finds itself in a rather difficult situation now, when a new round of its reform is underway. However, some of its institutes provide advisory services for clients in addition to basic research and are developing dynamically, for example, the Energy Research Institute.

Some institutes of the Academy of Sciences are respected domestically and internationally. The Institute of World Economy and International Relations (IMEMO) ranks 32nd in the world in the global rating of leading think-tanks (IMEMO 2015). One of the authors of this chapter founded and now heads the IMEMO Oil and Gas Dialogue Forum, which regularly holds energy seminars attended by representatives of the ministries, domestic and foreign oil and gas companies, NGOs and the expert community. Participants discuss major problems of the Russian and global energy sector, opportunities and risks for Russia and together search for efficient solutions. The forum is widely attended by mid-level managers and experts from Gazprom, so it is possible that some of the ideas discussed at these seminars influence company decision-making.

Despite the general decline of Russian science, there are petroleum R\&D institutes such as NIIgazekonomika, VNIPIgazdobycha, VNIPIneft or TatNIPIneft that are supported by energy companies, and they appear to be doing quite well. However, since they can be expected to serve their corporate sponsors, their independence is limited.

A few small research centres and consulting companies focusing on the oil and gas sector have been established, such as the Institute of Energy and Finance (founded in 2004) or Vygon Consulting (founded in 2013). They conduct high-quality research on oil and gas issues and provide advisory services to the government and oil companies. 
Although these new centres ensure competition and diversity in the scientific sphere, it is not always easy to determine whether they are truly independent in their research and conclusions. For instance, the Ministry of Energy has commissioned the Energy Strategy Institute and the Institute of Energy Studies to draft Russia's Energy Strategy towards 2035. However, it appears that the Ministry of Energy will approve and incorporate in the final version only those ideas and calculations that it finds appropriate. The Institute of Energy and Finance is currently involved in drafting the General Scheme of Oil Sector Development towards 2035. The General Scheme is based on the forecast of socio-economic development of Russia towards 2030 provided by the Ministry of Economic Development, which predicts that the average oil price in 2030 will be USD 93.7 per barrel (Belogorev 2015), and the authors of the General Scheme are constrained by these frameworks.

On the one hand, the involvement of these research institutes in drafting such high-level papers appears to confirm their influence on energy developments in Russia. On the other hand, both the Strategy and the General Scheme are general documents that will not necessarily be put into practice. Their predecessors have never been fully implemented, and their predictions have rarely come true. The institutes win the tenders for drafting such key documents, which seems an appropriate way of involving experts in the process; however, the tender criteria are not always transparent. For instance, in summer 2014 VNIIGAZ, the R\&D institute of Gazprom won the tender for drafting the General Scheme of Gas Sector Development up to 2035. This Gazprom subsidiary is likely to formulate the document in such a way as to be in line with the interests of the gas export monopoly.

In general, the influence of these research institutes and think-tanks depends on the personality and connections of their leadership, the quality of their research — and, importantly, on whether their conclusions and recommendations are palatable to the authorities.

Russian educational establishments can have some influence on the petroleum sector, since they train future managers and employees who will work either directly in the energy sector or in relevant ministries and organizations that deal with management of petroleum resources and 
revenues. In addition to teaching, they often conduct research, so they can have additional impact through the formulation of recommendations for relevant authorities or companies. The influence of educational establishments varies widely, depending on the status of their leadership, the composition of their Boards of Trustees, the quality of teaching and research and so on. The most influential educational establishments focused on the petroleum sector are the Gubkin Oil and Gas Academy and Tyumen Oil and Gas University. Of particular importance is the St. Petersburg Mining University, where both President Putin and Rosneft President Igor Sechin completed their PhD (kandidatskaya) degrees. High-impact general establishments that deal extensively with petroleum issues include the Higher School of Economics, the Presidential Academy of National Economy and Public Administration and the Moscow State Institute of International Relations (MGIMO).

\section{Mass Media}

The media, and television in particular, wield considerable influence, but from the year 2000 onwards, most Russian media have become instruments for shaping the kind of public opinion desired by the government and not agents in their own right (Heritage 2015). The Kremlin has increasingly taken direct control of key mass media-for example, the First Channel, Russia's largest television channel, which reaches $98.8 \%$ of the population. In many cases, media have come under the control of Gazprom or other state-controlled companies. Gazprombank owns Gazprom-Media, which was established in 1998. It reaches audiences of altogether 90 million people through various types of media (see Table 15.1).

Because a few independent critical mass media still exist, the Kremlin can refute claims that there is no freedom of the press in Russia. These media also provide outlets for the opposition to let off steam. Editors of independent mass media rarely experience direct pressure from the authorities, but the Kremlin has financial (through impact on advertisers and sponsors), legislative and judicial levers. The number of independent media is also gradually shrinking. 
Table 15.1 Media managed by Gazprom-Media

\begin{tabular}{lll}
\hline Television channels & Radio stations & Other \\
\hline NTV & Avtoradio & Seven Days publishing house \\
TNT & Energy & Tribune newspaper \\
TV-3 & Humor FM & Panorama TV guide \\
Friday! & Radio Romantika & NTV+ satellite operator \\
2 X2 & Comedy Radio & Rutube video hosting \\
35 other TV channels & Like FM & now.ru online cinema \\
& Relax FM & Central Partnership \\
& Children's Radio & NTV-Cinema \\
& Echo of Moscow & Comedy Club \\
& 101.ru & \\
\hline
\end{tabular}

Source: Gazprombank 2016

Certain TV channels that are to varying degrees independent offer coverage of petroleum issues.

The RBC TV Channel discusses important oil and gas sector issues in a professional way. For example, one of its guests in 2016 was Vladimir Feigin, President of the Institute for Energy and Finance, who participated in the programme, 'State Support of the Oil and Gas Sector: Is it Needed or Not?' Low oil prices in 2014-2016 (and the implications for the petroleum sector and the Russian economy in general) was a hot media topic, and RBC broadcasts the programme 'Oil Companies have Calculated a Stress-Scenario below the Price of USD 30 for 2016: Oil Production Will not Suffer, but the State Budget will Have a Short-Fall of USD 50 Bln' (Pobedova 2015). In January 2016, RBC anchorman Igor Vittel hosted a programme where the First Deputy Minister of Energy Alexei Teksler and Grigoriy Vygon, head of Vygon Consulting, discussed the dependence of Russian gasoline prices on world oil prices, the cost of aviation kerosene, and what the sector should expect with oil at USD 20 per barrel. However, in May 2016 the three main editors at RBC resigned, citing political pressure (Boleckaya 2016). This may have signalled the beginning of the end of RBC's independence.

The television channel Dozhd, founded in 2010, is a 24-hour Russian news TV channel and media holding that provides news, analytical content and debates. It has given broad coverage to many controversial 
issues, such as the 2011-2013 protest movement in Moscow and other major Russian cities against the Russian government, and the political protest punk group Pussy Riot. The channel invites the Kremlin's persona non grata, such as former Yukos owner Mikhail Khodorkovsky, to speak on its shows. Consequently, the channel is regularly criticized and inspected by regulators and law enforcement bodies. Dozhd experienced serious financial problems when advertisers left the channel under pressure from the Kremlin and is now able to make broadcasts via the internet only.

Dozhd provides extensive coverage of oil and gas issues. A notable example was the roundtable organized on 17 October 2014, advertised as 'Mother Oil: Who caused the oil price drop, how much it will cost Putin, and are Kudrin and Leontiev right when they say that the price of oil is falling because of a global conspiracy?' The discussion centred on why the price of oil is falling, what prices level the Russian economy could bear and whether cheap oil will change Russia's foreign policy. Invited guests were Mikhail Krutikhin from RusEnergy, Lev Snykov, partner of Greenwich Capital, Marcel Salikhov from the Institute of Energy and Finance, Alexei Knizhnikov from WWF Russia, Mikhail Kasyanov, cochairman of RPR-PARNAS and Dmitriy Lyutyagin, independent oil and gas expert.

The radio station Echo of Moscow is highly popular and sometimes politically controversial. Its target audience is well-off, educated Muscovites, in the 40+ age bracket. Interestingly, 66\% of its shares are held by Gazprom-Media, with the remainder divided among the journalists of the station. Its Board of Directors includes four directors from Gazprom, three directors from within Echo of Moscow and two independent directors. Some experts believe that this popular radio station is the only independent mass media outlet in Russia and that its line is determined solely by its editor-in-chief (Business Online 2014). However, others disagree: the well-known journalist Vladimir Pozner has stated that 'there are almost no independent mass media remaining in Russia, and Echo of Moscow is only a pseudo-independent channel (because 66\% of the channel is owned by Gazprom-Media)' (Rustamova 2015). 


\section{Newspapers}

Newspapers have much less impact on public opinion than television in Russia but nonetheless provide important platforms for interaction and discussion among journalists, experts and elites. One of the most important broadsheets for the Russian petroleum sector is Vedomosti, a daily business newspaper launched in 1999 by the Dutch journalist Derk Sauer, currently with a print circulation of 75,000 . In 2013 , it had 26.8 thousand subscribers, including 4.9 thousand corporate subscribers. Until 2015, the newspaper was published by Sanoma Independent Media jointly with The Financial Times and The Wall Street Journal, each owner holding a 33\% stake. However, in the autumn of 2014, a law was adopted that had been put forward by several Duma deputies, prohibiting foreigners from owning more than 20\% of any Russian mass media outlet; the law entered into force on 1 January 2016. As a result, the foreign owners sold their shares to Demyan Kudryavtsev, the former Director General of the newspaper Kommersant. The fate of Vedomosti exemplifies the barring of previously important foreign influence in Russia.

Vedomosti covers the petroleum sector in its section 'Energy Resources'. It regularly quotes such high-profile moderate and neutral experts as Tatiana Mitrova, Maria Belova and Valery Nesterov. It has provided space both for pro-Kremlin energy experts, such as Konstantin Simonov, and for members of the opposition, such as Vladimir Milov. Also, Mikhail Khodorkovsky's articles and interviews have been published in Vedomosti.

Two other important newspapers that often write on petroleum-sector issues are Kommersant (circulation of paper edition: 125,000) and Nezavisimaya gazeta (circulation of paper edition: 40,000). The latter has a supplement titled NG-Energy that brings well-informed articles on oil and gas issues written by a broad range of experts, from pro-Kremlin to opposition.

In addition to the newspapers, there are some magazines that cover the petroleum sector. The two best-known are Neft $i$ kapital (paper edition circulation: 12,000) and Neftegazovaya vertikal (paper edition circulation: 15,000). They provide solid expert coverage of most key problems in the sector and quote a wide range of experts. 
Finally, the Russian population is highly active on social networks (Reuter and Szakonyi 2015), with the home-grown companies V kontakte, Odnoklassniki and Moi mir all larger than Facebook, which is also popular. The platforms provide obvious channels for public debate but have also come under scrutiny and pressure from the authorities (Pallin 2017, 16; Pearce 2015). Russian actors sometimes also use more specialized petition websites such as democrator.ru and change.ru. Some energy experts have started posting their views and analysis on social media, and sometimes they also generate discussion. However, so far they do not appear to have much impact on government policy.

\section{The General Population}

Ordinary Russians have little impact on how the country's petroleum reserves are managed. Indeed, they generally have no real interest in or understanding of the sector: of much greater personal importance to them is the distribution of oil and gas wealth. Many Russians are against heavy foreign involvement in the energy sector; they tend to see oil and gas as natural government monopolies, believe it was wrong to privatize the industry and feel that gas and petrol prices should be lower (Overland and Kutschera 2011).

Ordinary Russians, particularly those living in the oil- and gasproducing parts of the country, can try to influence developments by participating in public hearings held by oil and gas companies on new petroleum projects. In late 2015, LUKOIL-Komi organized a series of public hearings in the town of Ukhta concerning development of the Yareg oilfield. According to available information, from 11 to 26 people registered for each hearing (Mouhta.ru 2016), and it is difficult to say whether these were formal events or real discussions that could make a difference.

Though in general the Russian public is notoriously passive (Osipian $2016,215)$, a noteworthy event in relations between the local population and oil companies took place in 2014, when residents of the Izhma region in the Komi Republic held several meetings with representatives of LUKOIL-Komi, accusing the company of environmental violations 
and demanding that LUKOIL halt its activities in the area until it met the conditions formulated by its residents. The main reason for this demand was that LUKOIL had begun drilling near Krasnobor village without the necessary permits and without informing Krasnobor residents and local authorities (CSIPN 2014). Commenting on this situation, Vladimir Chuprov, head of the Energy Unit of Greenpeace Russia, said: 'we witnessed a really historic event that could provide a new direction in the development of civil society in Russia and in observing the integral human rights' (Chuprov quoted in Usov 2014). This development was indeed unique for Russia. A compromise was reached between the company and the Izhma region. LUKOIL continued its activities there, signing annual agreements on cooperation with the administration of the region (Municipal Region Izhemsky 2016). However, it is unclear whether civil society in general, and the local population of the petroleum regions in particular, would have been able to achieve a similar victory over the more powerful companies Gazprom or Rosneft.

Rosneft regularly publishes the results of public hearings on its website, usually showing that the participants wholeheartedly approve its projects. For instance, when Rosneft subsidiary the Far East Petrochemical Company conducted public hearings on the construction of a petrochemical complex in Nakhodka on Russia's Pacific coast, the local population and representatives of environmental and public organizations participated. The draft environmental impact assessment of the future complex had been made public prior to the hearings. The top management of the Far East Petrochemical Company met with local citizens and responded to their questions (Neftyanaya Vertikal 2016). Given the power of Rosneft, it may have been difficult for members of the public to take a negative stance in the hearings.

Although big companies like Gazprom or Rosneft may not be easily swayed by public hearings, smaller and less powerful companies may be more responsive. On 15 July 2015, repeat public hearings were held in Dudinka on the Taimyr peninsula, concerning the environmental impact assessments of the company Taimyrneftegazdobycha for the development of the Payakhsk and Severopayakhsk fields and the 
construction of the Tanalau oil terminal. The first hearings had been held on 30 April 2015 but were deemed invalid because of numerous violations and incomplete documentation submitted for review. The entire company management attended the second round. The Association of Small Indigenous Peoples of Taimyr invited Greenpeace to study and evaluate the materials provided by Taimyrneftegazdobycha (RAIPON 2015).

The hearing lasted for more than three hours. However, the Association of Small Indigenous Peoples of Taimyr, taking into account the opinion of residents of Baikalovsk, drew negative conclusions on the construction of Tanalau terminal on the Yenissei River: the risk of accidents was high, and the company had no experience of handling oil spills in winter and under the ice (RAIPON 2015). Taimyrneftegazdobycha is not yet an influential company, and there is a chance that the actions of NGOs and the local people might affect its decisions.

\section{Conclusions}

Russia's civil society engagement with the petroleum sector between 1991 and 2017 is surprisingly rich and varied for a country that ranks relatively low on most democracy-related indicators and where large parts of the population do not identify with the oil and gas industry (on Russian's identification with the petroleum sector, see Rutland 2015, 66). We have noted the lively and varied public debate, with business associations, research institutes, independent experts, environmental NGOs, indigenous organizations and a few remaining independent mass media actively and often competently analysing and commenting on a broad range of issues related to the oil and gas sector.

However, the real impact of civil society on decision-making and policy formulation in the petroleum sector is not as great as the diversity of actors and discussion might imply; the influence of the state on civil society and on public opinion is much stronger than the other way around. One key reason is the tight government control over the main media, especially television-whether directly or indirectly through 
Gazprom's media holdings, pressure on advertisers and other measures. Russia lacks the independent media element that could channel and amplify civil society awareness and discussion into real influence on the petroleum sector. The situation for free speech and civil society worsened steadily from around 2004 to 2017, and the full, long-term effects of this may not yet be fully noticeable.

Ironically, given the maturing oil and gas industry, and the growing domestic and international challenges facing Russia's petroleum sector, the intellectual input of a broad and diverse civil society and a more active public debate on petroleum issues in the few remaining independent mass media could have been highly valuable for decision-makers, helping maintain and strengthen Russia's position as a major energy producer and exporter.

\section{References}

Belogorev, Aleksei. 2015. Perspektivy rossiyskoy neftedobichy. Neftegazovyi dialog. http://imemo.ru/files/File/ru/conf/2015/10112015/20151110_PRZ_ BEL.pdf. Accessed on 28 September 2016.

Berezhkov, Dmitry. 2012. Why the Russian Government Shuts Down RAIPON: Background Article. http://www.iwgia.org/news/search-news?news_id=710. Accessed on 28 September 2016.

Boleckaya, Ksenia. 2016. Iz RBC ushli shef-redaktor, glavnye redaktory saita. Vedomosti, 13 May. http://www.vedomosti.ru/technology/articles/2016/05/ 13/640942-rbk-ushli\#/galleries/140737488872814/normal/1. Accessed on 28 September 2016.

Business Online. 2014. Glavnyi redaktor radio "Echo Moskvi" otvetit na voprosy chitateley. Business Online, 3 July. http://www.business-gazeta.ru/ online/206/. Accessed on 28 September 2016.

Chernobylets, Andrei, and Olga Shadrina. 2006. Kladovye na zamke. Expert Online, 30 January. http://expert.ru/siberia/2006/04/zakon_o_nedrah_ vyvody_55578/. Accessed on 28 September 2016.

Crotty, Jo, Sarah Marie Hall, and Sergej Ljubownikow. 2014. Post-Soviet Civil Society Development in the Russian Federation: The Impact of the NGO Law. Europe-Asia Studies 66 (8): 1253-1269. 
CSIPN. 2014. Zhiteli 16 sel vistupili s zayavleniem o priostanovke deyatelnosti Lukoil. http://www.csipn.ru/korennye-narody-i-promyshlennye-kompanii/ 910-zhiteli-16-sel-respubliki-komi-vystupili-s-zayavleniem--priostanovkedeyatelnosti-lukojl. Accessed on 28 September 2016.

Energy Future. 2010. Rossiyskaya neftyanaya katastrofa 1994 goda. 30 June. http://energyfuture.ru/rossijskaya-neftyanaya-katastrofa-1994-goda. Accessed on 28 September 2016.

Gazprombank. 2016. AO Gaprom-Media Holding. http://www.gazprombank. ru/group/company/7115/. Accessed on 28 September 2016.

Gilbert, Leah. 2016. Crowding Out Civil Society: State Management of Social Organisations in Putin's Russia. Europe-Asia Studies 68 (9): 1553-1578.

Gosudarstvennaya duma. 2012. Zakonoproekt №102766-6. O vnesenii izmenenii $\mathrm{v}$ otdelnye zakonodatelnye akty Rossiiskoi Federatsii v chasti regulirovaniya deyatelnosti nekommercheskih organizatsii, vypolnyaushikh funktsii inostrannogo agenta. http://asozd2.duma.gov.ru/main.nsf/\%28Spra vkaNew\%29? OpenAgent\&RN=102766-6\&02 Accessed on 28 September 2016.

Greenpeace Russia. 2012. Predstavitely korennyh narodov Severa trebuyt zapretit neftegazovoe osvoenie Arktiki. Greenpeace Russia, 20 August. http://www. greenpeace.org/russia/ru/news/2012/August/19-08-2012-sovmestnoeobrahenie-korennyh-narodov-Arktiki/. Accessed on 28 September 2016.

Heritage, Timothy. 2015. V putinskoy Rossii nezavisimye SMI prodolzhayut svoi boy. InoPressa, 31 July. http://inopressa.ru/article/31Jul2015/reuters/ media.html. Accessed on 28 September 2016.

Ignatova, Marya. 2003. Premier zapretil chastnye nefteprovody. Izvestia, 10 January. http://izvestia.ru/news/271563. Accessed on 28 September 2016.

IMEMO. 2015. IMEMO zanyal vysokie pozitsii v vedushem reitinge analyticheskyh tsentrov. http://www.imemo.ru/index.php?page_id=502\&id=1484. Accessed on 28 September 2016.

Jackson, Camille. 2016. Legislation as an Indicator of Free Press in Russia: Patterns of Change from Yeltsin to Putin. Problems of Post-Communism 63 (5-6): 354-366.

Lee, Taedong, Erica Johnson, and Aseem Prakash. 2012. Media Independence and Trust in NGOs: The Case of Postcommunist Countries. Nonprofit and Voluntary Sector Quarterly 41 (1): 8-35.

Lenta.ru. 2016. Illaryonov, Andrei. https://lenta.ru/lib/14159508/. Accessed on 28 September 2016. 
Leonard, Ray. 2016. Khodorkovsky, Yukos, and Putin: The Achievement of Khodorkovsky, Why It Was Destroyed, and the Consequences. Problems of Post-Communism 63 (2): 121-126.

Lunden, Lars Petter, Daniel Fjaertoft, Indra Overland, and Alesia Prachakova. 2013. Gazprom vs. Other Gas Producers: Friends or Foes? Energy Policy 61: 663-670.

Malkova, Irina. 2010. Rosneft mogla prodat neft na nevygodnyh dlya sebya usloviyakh. Vedomosti, 27 May. http://www.vedomosti.ru/business/articles/2010/05/27/rosneft-mogla-prodat-neft-na-nevygodnyh-dlya-sebyausloviyah. Accessed on 28 September 2016.

Milov, Vladimir, and Ivan Selivakhin. 2005. Problemy energeticheskoy politiki Rossii. http://carnegieendowment.org/files/rosimusmir.pdf. Accessed on 28 September 2016.

Milov, Vladimir, and Boris Nemtsov. 2008. Putin and Gazprom. Novaya gazeta, 2 September. http://en.novayagazeta.ru/politics/8107.html. Accessed on 28 September 2016.

-2010. Putin: What 10 Years of Putin Have Brought. http://www.putinitogi.ru/putin-what-10-years-of-putin-have-brought/. Accessed on 28 September 2016.

Moe, Arild, Daniel Fjærtoft, and Indra Overland. 2011. Space and Timing: Why Was the Barents Sea Delimitation Dispute Resolved in 2010? Polar Geography 34 (2): 145-162.

Mouhta.ru. 2016. Obshestvennye i publichnye slushaniya-Portal administratsii MOGO Ukhta. http://mouhta.ru/news/Obshslush/. Accessed on 28 September 2016.

Municipal Region Izhemsky. 2016. Mezhdu Lukoilom i Izhemskim rayonom zaklyucheno ocherednoye soglashenie. 26 December. http://www.izhma.ru/ ru/news/1704/. Accessed on 2 February 2017.

Neftyanaya Vertikal. 2016. V Nahodke sostoyalis obshestvenye slushnia proyekta stroitelstva VNHK. http://www.sakhoil.ru/article_250_25.htm. Accessed on 28 September 2016.

Neftyanka. 2015. Masshtabniye proryvi: Top 5 krupneyshih razlivov nefte na nefteprodah.Neftyanka,20April.http://neftianka.ru/masshtabnye-proryvy-top5-krupnejshix-razlivov-nefti-na-nefteprovodax/. Accessed on 28 September 2016.

Henry, Laura A., Nysten-Haarala, Soili, Svetalana Tulaeva, and Maria Tysiachniouk. 2016. Corporate Social Responsibility and the Oil Industry in 
the Russian Arctic: Global Norms and Neo-Paternalism. Europe-Asia Studies 68 (8): 1340-1368.

Orttung, Robert, and Indra Overland. 2011. A Limited Toolbox: Explaining the Constraints on Russia's Foreign Energy Policy. Journal of Eurasian Studies 2 (1): 74-85.

Osipian, Ararat. 2016. Protesting Putin or Protecting Rights? Media Reflections on Reflective Student Activism. Contemporary Politics 22 (22): 215-231.

Overland, Indra. 2010. Russia’s Arctic Energy Policy. International Journal 65 (4): 865-878.

. 2011. Close Encounters: Russian Policymaking and International Oil Companies. In Russia's Encounter with Globalization: Actors, Processes and Critical Moments, ed. Julie Wilhelmsen and Elana Rowe, 134-158. Basingstoke: Palgrave Macmillan.

Overland, Indra, and Hilde Kutschera. 2011. Pricing Pain: Social Discontent and Political Willpower in Russia's Gas Sector. Europe-Asia Studies 63 (2): 311-329.

Overland, Indra, Jakub Godzimirski, Lars Petter Lunden, and Daniel Fjaertoft. 2013. Rosneft's Offshore Partnerships: The Re-opening of the Russian Petroleum Frontier? Polar Record 49 (249): 140-153.

Overland, Indra, and Andrey Krivorotov. 2015. Norwegian-Russian Political Relations and Barents Oil and Gas Developments. In International Arctic Petroleum Cooperation: Barents Sea Scenarios, ed. Anatoli Bourmistrov, Frode Mellemvik, Alexei Bambulyak, Ove Gudmestad, Indra Overland, and Anatoly Zolotukhin, 97-110. Abingdon: Routledge.

Overland, Indra. 2017. The Hunter Becomes the Hunted: Gazprom Encounters EU Regulation. In Energy Union: Europe's New Liberal Mercantilism? ed. Svein Andersen, Andreas Goldthau, and Nick Sitter, 115-130. Basingstoke: Palgrave Macmillan.

Pallin, Carolina Vendil. 2017. Internet Control through Ownership: The Case of Russia. Post-Soviet Affairs 33 (1): 16-33.

Pearce, Katy. 2015. Democratizing Kompromat: The Affordances of Social Media for State-Sponsored Harassment. Information, Communication and Society 18 (10): 1158-1174.

Pobedova, Ludmila. 2015. Neftyanye kompanii proschitaly stress-stsenarii pri tsene \$30. RBC, 24 December. http://www.rbc.ru/business/24/12/2015/567 c1dab9a7947d7b53a2b9c. Accessed on 28 September 2016. 
Popov, Igor. 2007. Staraya Gvardia. Forbes, 3 April. http://www.forbes.ru/ forbes/issue/2007-04/11807-staraya-gvardiya. Accessed on 28 September 2016.

Poussenkova, Nina. 2007. Lord of the Rigs: Rosneft as a Mirror of Russia's Evolution. http://www.bakerinstitute.org/files/2466/. Accessed on 29 September 2016.

- 2011. The Russian Oil Industry: Twenty Years That Shook the World. In History of the New Russia. St. Petersburg: Norma Publishing House.

RAIPON. 2015. Na Taimyre proshli obshestvennye slushania oceni vozdeistvya na okrujaushuu sredu po proektu OAO 'NNK-Taimyrneftegazdobycha'. http://www.raipon.info/info/news/1295/. Accessed on 28 September 2016.

Reuter, Ora John, and David Szakonyi. 2015. Online Social Media and Political Awareness in Authoritarian Regimes. British Journal of Political Science 45 (1): 29-51.

RSPP. 2016. Rossyiskyi Souz Promyshlennikov i Predprenimateley. Tochka Zreniya. http://www.rsppenergy.ru/rabota-komiteta/tochka-zreniya/. Accessed on 28 September 2016.

Russian President. 1992. Ob osobennostyakh privatizatsii i preobrazovaniya v aktsionernye obshchestva gosudarstvennykh predpriyatiy, proizvodstvennykh i nauchno-proizvodstvennykh obedineniy neftyanoy, neftepererabatyvayushchey promyshlennosti i nefteproduktoobespecheniya. Decree No 1403 of 17 November. http://www.kremlin.ru/acts/bank/2417. Accessed on 24 February 2017.

Rustamova, Farida. 2015. Pozner zayavil ob otsutstvii nezavisimoy jurnalistiki v Rossii. RBC, 25 May. http://www.rbc.ru/politics/25/05/2015/5562e3119a7 $947 \mathrm{e} 2 \mathrm{c} 215726 \mathrm{c}$. Accessed on 28 September 2016.

Rutland, Peter. 2015. Petronation? Oil, Gas and National Identity in Russia. Post-Soviet Affairs 31 (1): 66-89.

Sergeev, Nikolay, Oleg Rubnikovich, and Vladislav Trifonov. 2015. Chelovek na mostu. Kommersant, 2 March. http://www.kommersant.ru/doc/2678101. Accessed on 28 September 2016.

TPP. 2016. Missia torgovo promyshlenoy palaty Rossiyskoy Federatsii. https:// tpprf.ru/ru/mission/. Accessed on 28 September 2016.

Usov, Yevgeniy. 2014. Komi-izhemtsi ostanavlivayut Lukoil. http://www.csipn. $\mathrm{ru} /$ korennye-narody-i-promyshlennye-kompanii/910-zhiteli-16-sel-respubliki-komi-vystupili-s-zayavleniem--priostanovke-deyatelnosti-lukojl. Accessed on 28 September 2016. 
- 2016. Ekologicheskaya politika neftegazovogo sektora (zelenaya ekonomika). https://www.wwf.ru/about/what_we_do/oil. Accessed on 28 September 2016.

Yabloko. 2016. Yavlinskiy. http://www.yabloko.ru/Persons/Yavlinskiy.html/. Accessed on 28 September 2016.

Open Access This chapter is licensed under the terms of the Creative Commons Attribution 4.0 International License (http://creativecommons.org/ licenses/by/4.0/), which permits use, sharing, adaptation, distribution and reproduction in any medium or format, as long as you give appropriate credit to the original author(s) and the source, provide a link to the Creative Commons license and indicate if changes were made.

The images or other third party material in this chapter are included in the chapter's Creative Commons license, unless indicated otherwise in a credit line to the material. If material is not included in the chapter's Creative Commons license and your intended use is not permitted by statutory regulation or exceeds the permitted use, you will need to obtain permission directly from the copyright holder.

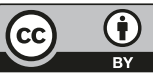

